\title{
The influence of matriptase- 2 on prostate cancer in vitro: A possible role for $\beta$-catenin
}

\author{
SIOBHAN L. WEBB, ANDREW J. SANDERS, MALCOLM D. MASON and WEN G. JIANG \\ Metastasis and Angiogenesis Research Group, Institute of Cancer and Genetics, \\ Cardiff University School of Medicine, Cardiff, UK
}

Received May 9, 2012; Accepted June 21, 2012

DOI: $10.3892 /$ or.2012.1945

\begin{abstract}
The type II transmembrane serine proteases (TTSPs) are a family of cell surface proteolytic enzymes contributing to a number of processes, such as tumour invasion and metastasis. Within the TTSPs, matriptase- 2 is a relatively newly identified member and this protease has been shown to play a key role in cancer progression. $\beta$-catenin has long been regarded as an oncogene. The deregulation of the $\beta$-catenin signalling pathway plays a significant role in the progression and possibly the development of cancer. However, little is known about the role of matriptase- 2 in prostate cancer. This study aimed to examine the correlation between matriptase- 2 and $\beta$-catenin. Matriptase-2 was knocked down in the normal prostate cells, PZHPV7 and PNT2C2, using a ribozyme transgene targeting matriptase-2. The altered cells were used in a number of in vitro experiments designed to investigate the involvement of matriptase- 2 with $\beta$-catenin and to further characterise its function. The knockdown of matriptase- 2 had no effect on cell growth or adhesion but significantly reduced cell motility (PZHPV7 cells, $\mathrm{p}<0.001$; PNT2C 2 cells, $\mathrm{p}=0.001$ vs. respective control cells) and invasive capability (PZHPV7 cells, $\mathrm{p}=0.001$; PNT2C2 cells, $\mathrm{p}=0.007)$. The knockdown also caused a large increase in $\beta$-catenin protein expression at the cell membrane in PZHPV7 and PNT2C2 cells and a decrease in PC3 cells overexpressing matriptase-2, but did not affect the mRNA levels. Matriptase-2 may have an important impact on prostate cancer progression. The data gained from this study suggest that matriptase- 2 protects against the development and progression of prostate cancer by regulating the motility and invasive capabilities of prostate cancer cells. Matriptase- 2 also reduces the levels of $\beta$-catenin at the cell membrane. As $\beta$-catenin is highly involved in the regulation of cellular processes, including motility and
\end{abstract}

Correspondence to: Professor W. Jiang, Metastasis and Angiogenesis Research Group, Institute of Cancer and Genetics, Department of Surgery, Cardiff University School of Medicine, Heath Park, Cardiff CF14 4XN, UK

E-mail: jiangw@cf.ac.uk

Key words: matriptase-2, type II transmembrane serine protease, $\beta$-catenin, prostate cancer invasion, the reduction of $\beta$-catenin expression by matriptase- 2 may be a possible mechanism by which matriptase- 2 functions.

\section{Introduction}

Matriptase-2 is a member of the type II transmembrane serine protease (TTSP) family, a family of proteases, which has attracted significant scientific interest due to differential expression patterns in normal and cancerous tissue and cells (1-5). The matriptase- 2 gene is located on chromosome 22 encoding an $88,901-\mathrm{kDa}$ molecular weight protein (6). The protein structure of matriptase-2 is characteristic of that of the TTSP group, consisting of a mixture of domains common to this family of proteases and has been described in a number of studies $(7,8)$. Matriptase-2 shares homology with matriptase-1, another TTSP whose expression is altered in various human cancers (9). However, whereas the overexpression of matriptase-1 leads to cancer progression $(10,11)$, matriptase- 2 overexpression significantly reduces breast and prostate cancer growth and the reduced expression of matriptase- 2 is associated with poor patient outcome $(12,13)$. This difference in apparent functions of both proteases has prompted more in depth investigation into the potential anti-metastatic properties of matriptase-2. Currently, the molecular mechanisms involved in the activation and regulation of matriptase-2 remain largely unknown due to the small number of studies currently investigating matriptase- 2 .

Cancer cells arise from normal cells via mutation. These mutations allow the previously non-cancerous cells to gain characteristics facilitating the progression to an aggressive phenotype. A cancer cell relies on a number of vital biological processes with which to establish itself in its environment and to subsequently metastasise. The most significant of these include changes in cell growth and invasive and migratory capacities. Cancer cells can influence these processes in several ways, most significantly by altering the expression of molecules that play key roles in controlling these cellular traits. Matriptase-2 has previously shown the ability to reduce the migration of PC3 and DU145 cells and the adhesion of PC3 cells (13).

$\beta$-catenin was first described as a structural component in adherens junction formation, a mechanism of cell-cell adhesion and is normally maintained at low levels in the absence of Wnt stimulation, due to its constitutive proteasomal degradation (14). The reduction of $\beta$-catenin degradation upon Wnt stimulation leads to the increased participation of $\beta$-catenin in two major 
cellular processes: nuclear signalling and cell-cell adhesion. $\beta$-catenin accumulation in the cytoplasm results in its translocation into the nucleus and interaction with DNA-binding transcription factors, the most prominent of which are those of the T cell-specific transcription factor (TCF)/lymphoid enhancer factor (LEF) family. Once localized to the nucleus, the complex formed between $\beta$-catenin and its DNA-binding transcription factors initiates the transcription of its target genes. These target genes are highly involved in the regulation of many proteins that are involved in maintaining the proper functions of the cell. These target genes include c-MYC (15), MMP-7 (16,17), VEGF (18) and MET (19). Due to the importance of these target genes in maintaining the correct function of the cell, the balance between the degradation and activation of $\beta$-catenin must remain tightly controlled. The deregulation of this pathway plays a significant role in the progression and possibly the development of cancer.

In the present study, the expression of matriptase- 2 was knocked down in the normal prostate cell lines, PZHPV7 and PNT2C2, using a ribozyme transgene targeting matriptase-2. The biological functions of these cells were subsequently examined. In order to investigate any link between matriptase- 2 and $\beta$-catenin, matriptase- 2 expression was also forced in the aggressive prostate cancer cell lines, PC3 and DU145. A mammalian expression plasmid containing the matriptase-2 gene was used to produce the overexpressed cell lines.

\section{Materials and methods}

Cell lines and culture conditions. The prostate epithelial cell line, PZHPV7, was purchased from the American Type Culture Collection (ATCC; Rockville, MD). PNT2C2 prostate epithelial cells were a kind gift from Professor Norman Maitland (University of York, York, UK). These cells were maintained in Dulbecco's modified Eagle medium (DMEM) (PAA Laboratories Ltd., Somerset, UK), supplemented with penicillin, streptomycin and $10 \%$ foetal calf serum (PAA Laboratories Ltd.) and incubated at $37^{\circ} \mathrm{C}, 5 \% \mathrm{CO}_{2}$ and $95 \%$ humidity.

Generation of cell lines displaying altered expression of matriptase-2. The ribozyme transgene was generated using touchdown PCR before being inserted into a pEF6/V5-His-TOPO plasmid and cloned into $E$.coli. The plasmids were then checked to ensure that the ribozyme was in the correct orientation. PZHPV7 and PNT2C2 cells were subsequently transfected with this plasmid. The matriptase- 2 coding sequence had previously been cloned into a pEF6/V5-His-TOPO plasmid vector in our laboratory (12). PC3 cells had also been previously transfected with the matriptase-2 expression plasmid (13). These cells were utilised in this study. To ensure that an efficient/stable transfection was achieved, the cells were placed into a selection medium $(5 \mu \mathrm{g} / \mathrm{ml}$ blasticidin), utilising the blasticidin resistance gene coded on the pEF6 plasmid to select cells containing the plasmid. Cells were subsequently cultured in maintenance medium $(0.5 \mu \mathrm{g} / \mathrm{ml}$ blasticidin) and routinely tested to confirm matriptase- 2 overexpression or knockdown. Cells containing the ribozyme transgene were termed PZHPV7 $7^{\text {mat2 ribl }}$ and PNT2C2 $2^{\text {mat2 ribl }}$, whereas PC3 cells containing the expression plasmid were designated as $\mathrm{PC}^{\text {mat2 exp }}$. Similarly, cells containing a closed pEF6 plasmid (containing no expression sequence/ribozyme transgene, to demonstrate the lack of effects exerted by the plasmid alone) were termed PZHPV7 $7^{\mathrm{pEF}}, \mathrm{PNT}_{2} \mathrm{C}^{\mathrm{pEF} 6}$ and $\mathrm{PC}^{\mathrm{pEF} 6}$.

$R N A$ extraction, quantification and RT-PCR. Cells were grown to confluence in a $25 \mathrm{~cm}^{2}$ tissue culture flask before extracting RNA from the cells using TRI reagent (Sigma, Dorset, UK) in accordance with the provided protocol. Subsequently, RNA concentration was calculated using a spectrophotometer (WPA UV 1101, Biotech Photometer, Cambridge, UK) and samples were standardised to $250 \mathrm{ng}$ prior to undertaking reverse transcription (enhanced avian reverse transcriptase-PCR-100; Sigma). The quality of the cDNA generated was tested using GAPDH primers (full primer sequences are outlined in Table I).

Quantitative-polymerase chain reaction ( $Q-P C R)$. Matriptase-2 transcript levels in each of the samples were detected using the iCycler IQ system. The results are presented as the number of transcripts/ $\mu \mathrm{g}$ RNA, based on an internal standard. Matriptase-2 transcript levels were normalised within each sample in relation to the expression of GAPDH. For the Q-PCR analysis, the Amplifluor system (Intergen Inc., Purchase, NY), Q-PCR Master Mix (ABgene, Surrey, UK) and a universal probe (Uniprimer) were used, recording emitted fluorescence. Conditions for Q-PCR were: an initial $15 \min 95^{\circ} \mathrm{C}$ period followed by 80 cycles of $95^{\circ} \mathrm{C}$ for $15 \mathrm{sec}, 55^{\circ} \mathrm{C}$ for $60 \mathrm{sec}$ and $72^{\circ} \mathrm{C}$ for $20 \mathrm{sec}$. Full details of primers used are presented in Table I.

SDS-PAGE and western blot analysis. Cells were grown to confluence, detached and lysed in a lysis buffer containing $0.5 \%$ SDS, $1 \%$ Triton X-100, $2 \mathrm{mM} \mathrm{CaCl}{ }_{2}, 100 \mathrm{mg} / \mathrm{ml}$ phenylmethylsulfonyl fluoride, $1 \mathrm{mg} / \mathrm{ml}$ leupeptin, $1 \mathrm{mg} / \mathrm{ml}$ aprotinin and $10 \mathrm{mM}$ sodium orthovanadate on a rotor wheel for $1 \mathrm{~h}$ before the removal of insolubles by centrifugation at 13,000 rpm. The Bio-Rad DC Protein Assay kit (Bio-Rad Laboratories, Hemel Hempstead, Hertfordshire, UK) was used to quantify protein levels in each sample and samples were subsequently standardised to $2 \mathrm{mg} / \mathrm{ml}$, diluted with Laemmli $2 X$ concentrate sample buffer (Sigma) and boiled for $5 \mathrm{~min}$. Samples were loaded, in equal quantities, onto a $10 \%$ acrylamide gel and subjected to electrophoretic separation. The proteins were blotted onto a Hybond-C Extra nitrocellulose membrane (Amersham Biosciences UK Ltd., Bucks, UK), blocked in $10 \%$ milk and subjected to specific antibody probing. Matriptase-2 expression was detected using matriptase-2 stem region-specific antibodies (Abcam, Cambridge, UK). The detection of the GAPDH housekeeping protein, to indicate uniform protein expression levels in the samples, was undertaken using an anti GAPDH antibody (Santa Cruz Biotechnology, Inc., Santa Cruz, CA).

Immunocytochemistry (ICC). A total of 20,000 cells in $200 \mu \mathrm{l}$ DMEM medium were seeded into chamber slides (Nalge Nunc International, Lab-Tek ${ }^{\circledR}$, Rochester, NY, USA) and left to incubate overnight at $37^{\circ} \mathrm{C}$, with $5 \% \mathrm{CO}_{2}$. After incubation the cells were fixed with $200 \mu \mathrm{l}$ formalin for $20 \mathrm{~min}$ at $4^{\circ} \mathrm{C}$. Subsequent to fixation, the cells were rehydrated with $200 \mu$ BSS for a minimum of $30 \mathrm{~min}$ at room temperature. Cells were permeabilised with $0.1 \%$ Triton X-100, then incubated with $\beta$-catenin primary antibody for $1 \mathrm{~h}$. After 4 washes with wash buffer, the cells were incubated with $200 \mu 1$ of working Vectastain ${ }^{\circledR}$ 
Table I. Primer sequences.

\begin{tabular}{lll}
\hline Molecule & Primer name & \multicolumn{1}{c}{ Primer sequence } \\
\hline Matriptase-2 ribozyme & Matrip2 RZ1F & CTGCAGCACTAGAGATTCCCGGCGGGTAACTGATGAGTCCGTCAGGA \\
& Matrip2 RZ1R & ACTAGTTGTACTCAATCGGCACTTCTCCCAG \\
Matriptase-2 & Matrip2 F2 & GAAAGACATAGCTGCATTG \\
& Matrip2 R2 & GTAGTAGCTGGGGAAGTACG \\
GAPDH & GAPDH F10 & AGCTTGTCATCAATGGAAAT \\
& GAPDH R10 & CTTCACCACCTTCTTGATGT \\
Matriptase-2 & Matrip2 ZF & ACTGAACCTGACCGTACAGCCGAGTACGAAGTGGAC \\
(Q-PCR) & Matrip2 R2 & GTAGTAGCTGGGGAAGTACG \\
GAPDH & GAPDH ZF & ATGATATCGCCGCGCTCA \\
(Q-PCR) & GAPDH R10 & CTTCACCACCTTCTTGATGT \\
$\beta$-catenin & $\beta$-catenin F22 & AAAGGCTACTGTTGGATTGA \\
& $\beta$-catenin R22 & TCCACCAGAGTGAAAAGAAC \\
\end{tabular}

Universal secondary antibody for $30 \mathrm{~min}$, followed by extensive washing and further incubation with ABC complex (Vector Laboratories Inc., Burlingame, USA). Following the removal of the ABC solution, a few drops of DAB chromogen (Vector Laboratories Inc.) were added to the cells and left to incubate for $5 \mathrm{~min}$ in the dark. The cells were then counterstained with Mayer's haematoxylin for approximately $1 \mathrm{~min}$.

Immunofluorescent (IFC) staining. A total of 20,000 cells in $200 \mu$ l DMEM medium were seeded into chamber slides (Nalge Nunc International, Lab-Tek ${ }^{\circledR}$ ) and left to incubate overnight at $37^{\circ} \mathrm{C}$, with $5 \% \mathrm{CO}_{2}$. After incubation, the medium was aspirated and the cells fixed with $200 \mu \mathrm{l}$ ice-cold pure ethanol for $20 \mathrm{~min}$ at $4^{\circ} \mathrm{C}$. Subsequent to fixation, the cells were rehydrated with $200 \mu \mathrm{l}$ BSS for a minimum of $30 \mathrm{~min}$ at room temperature. Cells were permeabilised with $0.1 \%$ Triton X-100, and incubated with $\beta$-catenin primary antibody for $1 \mathrm{~h}$. The primary antibody was then washed off and replaced with the corresponding FITC-labelled secondary antibody (Sigma). FluorSave (Calbiochem-Novabiochem Ltd., Nottingham, UK) was added to the cells before placing a cover-slip over the slide. Following this, cells were viewed using a fluorescent microscope.

In vitro growth assay. Cells were seeded into triplicate 96-well plates at a density of 3,000 cells per well. Plates were then incubated for overnight, 3- or 5-day periods before being fixed in $4 \%$ formaldehyde (v/v) and stained with $0.5 \%(\mathrm{w} / \mathrm{v})$ crystal violet. The crystal violet stain absorbed by the cells was subsequently extracted using $10 \%$ acetic acid (v/v) and the cell density was determined by measuring the absorbance of this solution using a Bio-Tek ELx800 multi-plate reader (Bio-Tek Instruments Inc, Winooski, VT).

In vitro cell motility assay. A total of 500,000 cells were incubated in $10 \mathrm{ml}$ of growth medium containing $100 \mu \mathrm{l}$ of cytodex-2 beads (GE Healthcare, Cardiff, UK) for $3.5 \mathrm{~h}$ to allow cell adherence to the cytodex beads. The beads were then carefully washed twice in $5 \mathrm{ml}$ of normal medium to remove non-adherent or dead cells. Following the second wash, the beads were re-suspended in $5 \mathrm{ml}$ of growth medium and $300 \mu \mathrm{l}$ of this solution was then added to a 96-well plate and incubated overnight at $37^{\circ} \mathrm{C}, 5 \% \mathrm{CO}_{2}$ and $95 \%$ humidity. Following incubation, the cells that had migrated from the cytodex- 2 beads and adhered to the base of the well were fixed in $4 \%$ formaldehyde and stained with $0.5 \%$ crystal violet and counted.

In vitro Matrigel adhesion assay. A total of 45,000 cells were seeded into the wells of a 96-well plate that had been previously coated with $5 \mu \mathrm{g}$ of Matrigel artificial basement membrane. Cells were incubated for $45 \mathrm{~min}$ before being subjected to washing in BSS to remove non-adherent cells, after which adherent cells were fixed in $4 \%$ formaldehyde (v/v), stained with $0.5 \%(\mathrm{w} / \mathrm{v})$ crystal violet and counted under a microscope.

In vitro invasion assay. A total of 40,000 cells were seeded into transwell inserts containing $8-\mu \mathrm{m}$ pores, that had previously been coated with $50 \mu \mathrm{g}$ Matrigel, in a 24-well plate and were incubated for a period of 3 days. Following incubation, cells which had degraded and migrated through the Matrigel to the other side of the insert were fixed in formaldehyde, stained with crystal violet and counted under a microscope.

Statistical analysis. Statistical comparisons relative to the control cell lines containing an empty pEF6 vector were made. Data were analysed using the Minitab 14 software and statistical comparisons were drawn using the two samples: two-tailed t-test or the Mann-Whitney non-parametric test. All experimental procedures were repeated for minimum of three times. A p-value $<0.05$ was considered to indicate a statistically significant difference.

\section{Results}

Confirmation of knockdown in PZHPV7 and PNT2C2 cells. PZHPV7 and PNT2C2 cells were chosen as they expressed matriptase-2 at a high level (Fig. 1A). To confirm matriptase-2 knockdown at the mRNA levels, Q-PCR was performed and showed that there was a visible reduction in matriptase- 2 mRNA levels in both cells lines compared to the respective wild-type and plasmid control cell lines (Fig. 1B and C). To confirm matriptase- 2 knockdown at the protein level, two methods were 

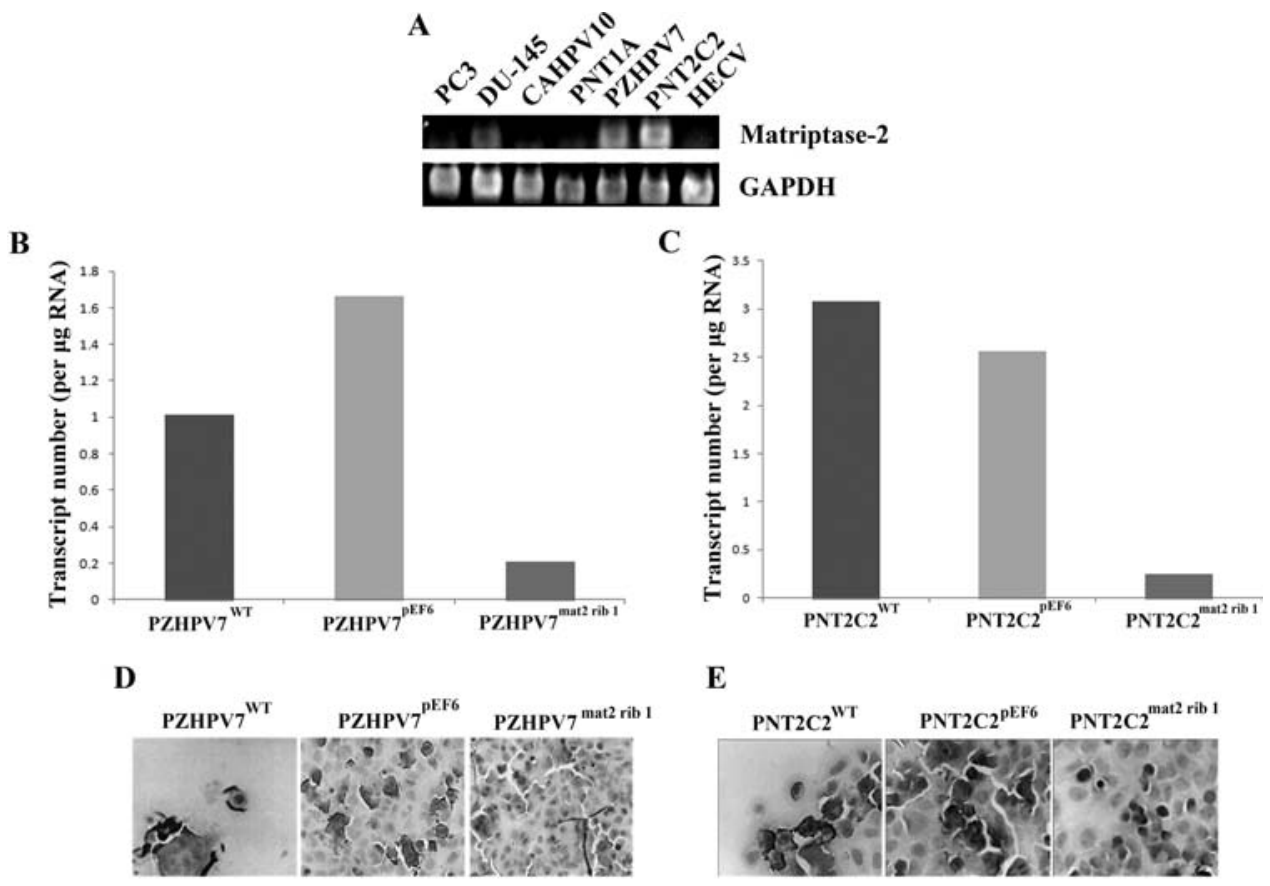

$\mathbf{E}$
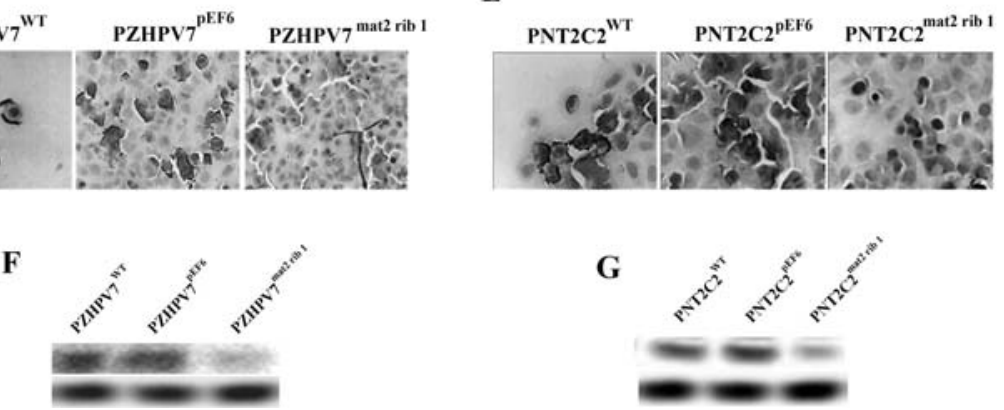

Figure 1. Confirmation of knockdown of matriptase-2 in PZHPV7 and PNT2C2 cells. (A) RT-PCR analysis revealed a high expression of matriptase-2 in PZHPV7 and PNT2C2 cells. (B) Q-PCR was used to confirm the knockdown of the matriptase-2 mRNA transcript in the PZHPV7 ${ }^{\text {mat } 2 \text { ribl }}$ cell line (C) Q-PCR was used to confirm the knockdown of the matriptase- 2 mRNA transcript in the PNT2C $2^{\text {mat } 2 \text { ribl }}$ cell line. (D and E) Immunocytochemistry (ICC) was used to demonstrate the knockdown of matriptase-2, at the protein level, in PZHPV7 and PNT2C2 cells containing the matriptase-2 ribozyme transgene plasmid, using a commercially available antibody. Matriptase-2 levels were found to be successfully knocked down in both cell lines. (F and G) Suppression of matriptase-2 protein expression was also demonstrated in PZHPV7 and PNT2C2 cells transfected with the matriptase-2 ribozyme transgene in comparison to the respective controls using western blot analysis.

used. ICC staining revealed that there was indeed matriptase-2 knockdown at the protein level. This also showed the position of matriptase-2 at the cell membrane (Fig. 1D and E). Western blot analysis also confirmed matriptase-2 protein knockdown in both the PZHPV7 ${ }^{\text {mat2 ribl }}$ and PNT2C $2^{\text {mat2 rib1 }}$ cells compared to the respective wild-type and plasmid control cell lines (Fig. 1F and G).

Matriptase-2 has no effect on PZHPV7 or PNT2C2 cell growth or adhesion. The impact of matriptase-2 knockdown appeared to have little effect on the in vitro growth rates of PZHPV7 and PNT2C2 cells. There were no obvious differences in the growth rates of PZHPV7 ${ }^{\text {mat2 ribl }}$ cells compared to the control cells (Fig. 2A). Cell growth at 5 days was not significantly different in the PZHPV7 ${ }^{\text {mat2 rib1 }}$ cells $(478.20 \pm 72.27)$ compared to the control PZHPV7 ${ }^{\text {pEF6 }}$ cells $(495.88 \pm 132.99 ; \mathrm{p}=0.716)$. Similarly, there was also no significant difference in cell growth observed in the PNT2C2 cell line. Cell growth at 5 days was not significantly different in the PNT2C2 ${ }^{\text {mat2 ribl }}$ cells $(367.65 \pm 71.54)$ compared to the PNT2C2 $2^{\mathrm{pEF} 6}$ cells $(347.14 \pm 115.04 ; \mathrm{p}=0.711)$ (Fig. 2B). The cells were further analysed for their adhesive capacity in an in vitro Matrigel adhesion assay. Cells displaying a suppressed level of matriptase-2 displayed little difference in adhesive capacity compared to the respective control lines. There was no significant difference in cell adhesion in the PZHPV7 ${ }^{\text {mat2 rib1 }}$ cells $(29.36 \pm 4.90)$, compared to the control PZHPV7 ${ }^{\mathrm{pFF}}$ cells (31.20 \pm 7.03; p=0.465) (Fig. 2C). Similarly, no significant difference in cell adhesion was observed in the PNT2C2 $2^{\text {mat2 }}$ ribl cells $(101.53 \pm 24.64)$ compared to the control PNT2C2 $2^{\mathrm{pEF} 6}$ cells (100.33 \pm 27.25 ; p=0.900) (Fig. 2D).

Knockdown of matriptase-2 significantly increases the motility and invasive capabilities of PZHPV7 and PNT2C2 cells. The motility of both cell lines was examined using a cytodex- 2 bead assay. The matriptase- 2 knockdown cells displayed a significant difference in their motility rates compared to control cells. A significant increase in cell motility was observed in the PZHPV7 ${ }^{\text {mat2 ribl }}$ cells $(118.33 \pm 12.02)$ compared to the control PZHPV7 $7^{\mathrm{pEF} 6}$ cells $(61.20 \pm 9.05 ; \mathrm{p}<0.001)$ (Fig. 3A). There was also a significant increase in cell motility in the PNT2C2 $2^{\text {mat2 ribl }}$ cells $(103.40 \pm 8.83)$, compared to the control PNT2C2 $2^{\mathrm{pEF} 6}$ cells (59.93 \pm 9.67 ; $\mathrm{p}<0.001)$ (Fig. 3B). The cells were further analysed for their invasive capability. The knockdown of matriptase- 2 in these prostate epithelial cells significantly altered their invasive capacities. A significant increase in invasion was observed in the PZHPV7 ${ }^{\text {mat2 ribl }}$ cells $(21.50 \pm 0.70)$ compared to the control PZHPV7 ${ }^{\mathrm{pEF} 6}$ cells $(7.00 \pm 0.00 ; \mathrm{p}=0.001)$ (Fig. 3C). In keeping with this trend, a significant increase in invasiveness was also observed in the PNT2C2 ${ }^{\text {mat2 ribl }}$ cells $(55.00 \pm 10.71)$, compared to the control PNT2C2 $2^{\mathrm{pEF} 6}$ cells $(33.25 \pm 6.18 ; \mathrm{p}=0.007)$ (Fig. 3D). 
A

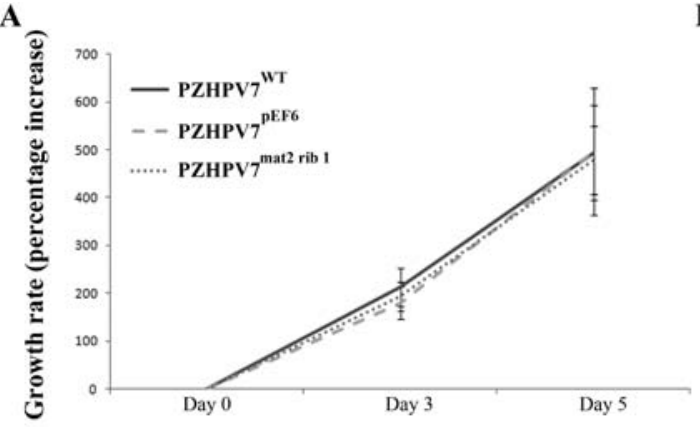

C
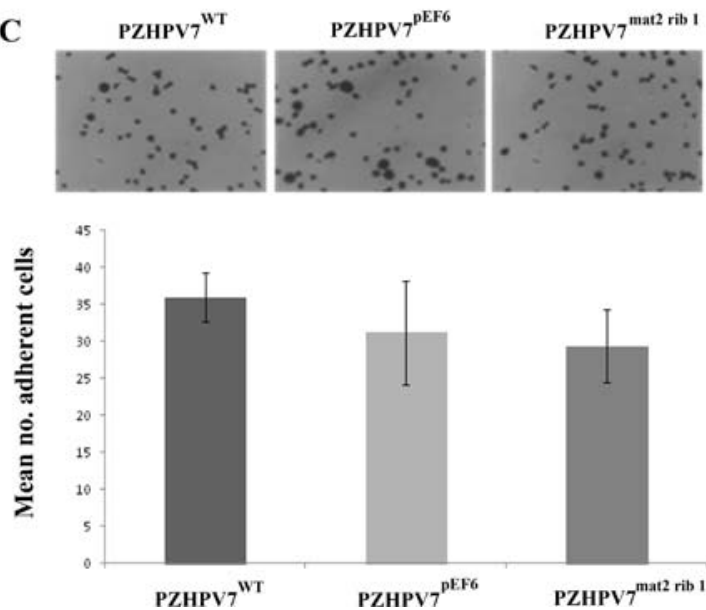

B
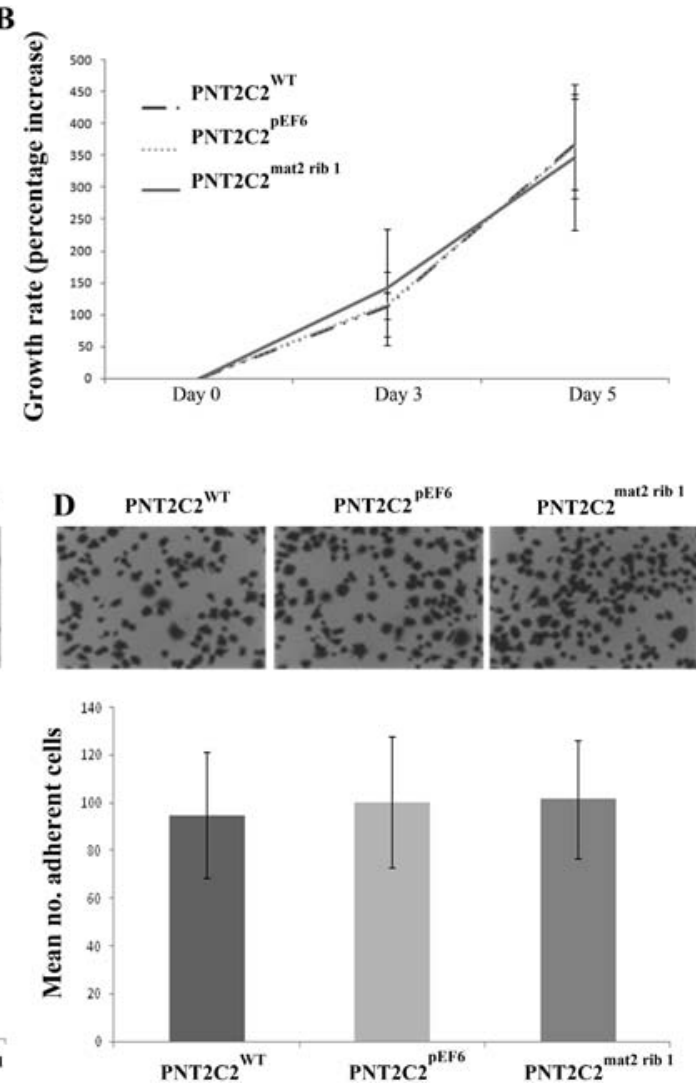

Figure 2. An in vitro growth assay was used to determine the effect of matriptase-2 knockdown in PZHPV7 and PNT2C2 cells. (A) Cell growth at 5 days was not found to be significantly different in the PZHPV ${ }^{\text {mat } 2 \text { ribl }}$ cells compared to the control PZHPV7 ${ }^{\text {PEF6 }}$ cells $(\mathrm{p}=0.716$ ). (B) Similarly, cell growth at 5 days was not significantly different in the PNT2C2 ${ }^{\text {mat2 ribl }}$ cells compared to the PNT2C2 $2^{\mathrm{pEF} 6}$ cells $(\mathrm{p}=0.711)$. The cells were further analysed for their adhesive capacity in an in vitro Matrigel adhesion assay. (C) There was no significant difference in cell adhesion in the PZHPV7 ${ }^{\mathrm{mat} 2 \text { ribl }}$ cells, compared to the control PZHPV $7^{\mathrm{pEF} 6}$ cells $(\mathrm{p}=0.465)$. (D) There was also no significant difference in cell adhesion in the PNT2C $2^{\text {mat } 2 \text { ribl }}$ cells, compared to the control PNT2C2 $2^{\mathrm{pEF} 6}$ cells $(\mathrm{p}=0.900)$. Values represent the mean \pm standard deviation; images of representative microscopic fields are shown.

Knockdown of matriptase-2 increases expression of $\beta$-catenin protein. $\beta$-catenin expression was examined in PZHPV7 ${ }^{\text {mat2 ribl }}$, $\mathrm{PNT} 2 \mathrm{C} 2^{\text {mat2 ribl }}$ and $\mathrm{PC} 3^{\text {mat2 exp }}$ cells. This revealed no change in $\beta$-catenin mRNA levels in the PZHPV7 ${ }^{\text {mat2 rib1 }}$ cells (Fig. 4A) but showed increased levels of $\beta$-catenin at the protein level following western blot analysis (Fig. 4B). IFC revealed that the increased levels of $\beta$-catenin protein were localised in the cell membrane (Fig. 4C). PNT2C2 cells followed a similar trend, with no obvious change in $\beta$-catenin mRNA expression (Fig. 4D), but an increased level of $\beta$-catenin protein expression (Fig. 4E), which was subsequently found to be localised in the cell membrane (Fig. 4F). To further investigate the effect of matriptase- 2 on $\beta$-catenin, the PC 3 cell line overexpressing matriptase- 2 was used in similar experiments. There was no change in $\beta$-catenin mRNA levels in this cell line (Fig. 4G). However, a decrease in the $\beta$-catenin protein level was observed in the PC $3^{\text {mat2 exp }}$ cells compared to the control cells (Fig. $4 \mathrm{H}$ ) and this reduction was apparent at the cell membrane following IFC staining (Fig. 4I).

\section{Discussion}

An increase in the cellular levels of $\beta$-catenin resulting from mutations in $\beta$-catenin itself, or in components of the destruction complex, is frequently observed in many cancer cells, including prostate cancer. The detection of $\beta$-catenin mutations in prostate cancer samples has been reported previously, with approximately $5 \%$ of samples revealing mutations at the serine or threonine residues in the NH2-terminal of the $\beta$-catenin protein (20-22). The examination of the $\beta$-catenin protein by ICC has revealed the aberrant localization of the protein in prostate cancer specimens $(23,24)$. Alterations of APC and b-TrCP1, which directly affect the degradation of $\beta$-catenin, have also been observed in prostate cancer samples (21). The direct role of $\beta$-catenin in promoting prostate cancer cell growth has been previously examined. The biological role of $\beta$-catenin in the tumorigenesis of prostate cancer was further characterized using a transgenic mouse model (25). The specific expression of a mutant $\beta$-catenin, lacking exon 3 , in prostate tissues has been shown to result in the development of prostate intraepithelial neoplasia (PIN), a precursor to prostate cancer, in mice ranging between 10-21 weeks of age (25). However, using similar approaches, another study observed hyperplasia of the prostate and squamous metaplasia but no PIN lesion in a similar animal model (26). Although the precise mechanism of $\beta$-catenin in the development of prostate cancer remains unclear, the above data have provided a solid link between $\beta$-catenin and the pathogenesis of prostate cancer.

To fully investigate the effect of matriptase- 2 on $\beta$-catenin, the aggressive prostate cancer cell line, PC3, was utilised in the experiments, along with the prostate epithelial cell lines, PZHPV7 and PNT2C2. The PC $3^{\text {mat2 exp }}$ cell line was previously 
A
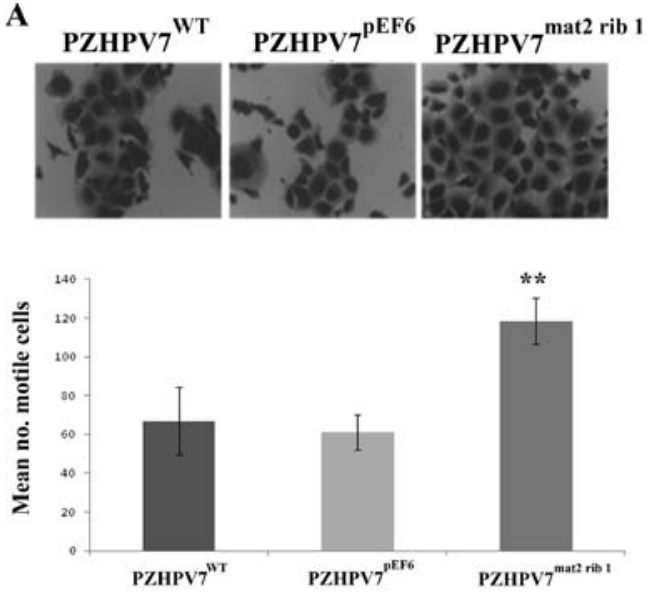

C
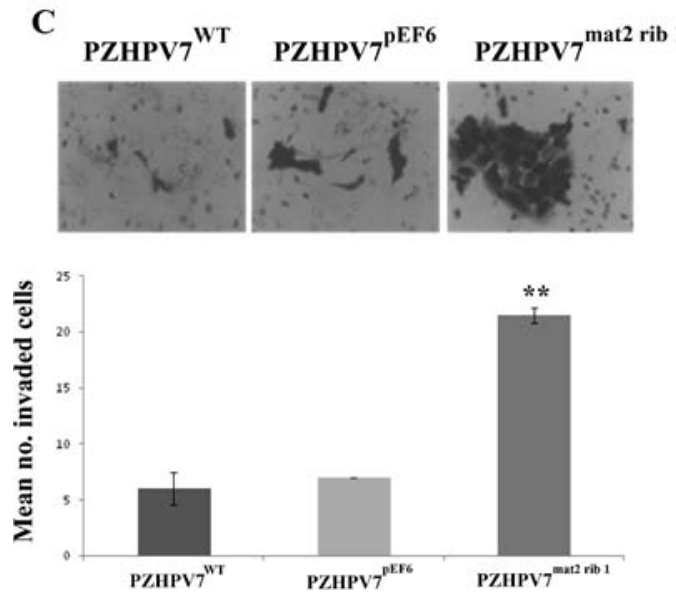
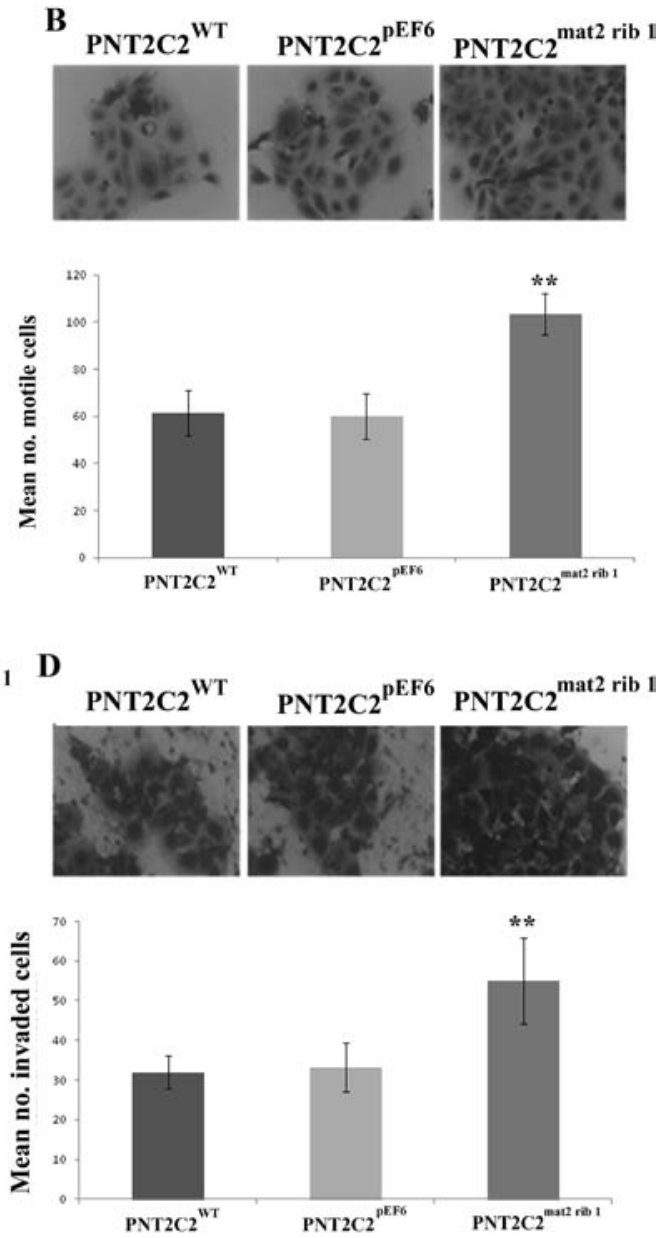

Figure 3. (A) The motility of both cell lines was examined using a cytodex-2 bead assay. There was a significant increase in cell motility in the PZHPV7 ${ }^{\text {mat ribl }}$ cells compared to the control PZHPV7 $7^{\mathrm{pEF} 6}$ cells $(\mathrm{p}<0.001)$. (B) There was also a significant increase in cell motility in the PNT2C2 ${ }^{\text {mat } 2 \text { ribl }}$ cells compared to the control PNT2C2 $2^{\mathrm{pEF} 6}$ cells $\mathrm{p}<0.001$. (C) The cells were further analysed for their invasive capability. There was a significant increase in invasion in the PZHPV7 ${ }^{\text {mat } 2 \text { ribl }}$ cells compared to the control PZHPV7 $7^{\mathrm{PEF} 6}$ cells $(\mathrm{p}=0.001)$. (D) There was also a significant increase in invasiveness in the PNT2C2 ${ }^{\text {mat2 ribl }}$ cells compared to the control PNT2C2 $2^{\mathrm{pEF} 6}$ cells $(\mathrm{p}=0.007)$. Values represent the mean \pm standard deviation; images of representative microscopic fields are shown.
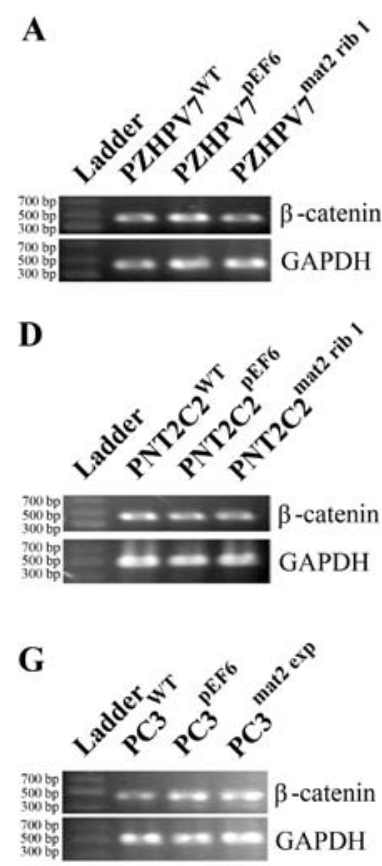

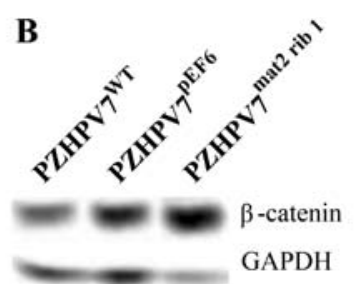

C
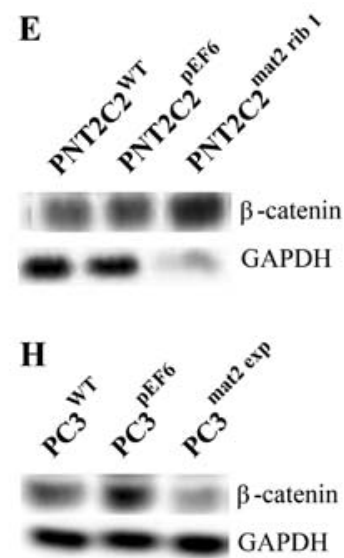

$\mathbf{F}$

I
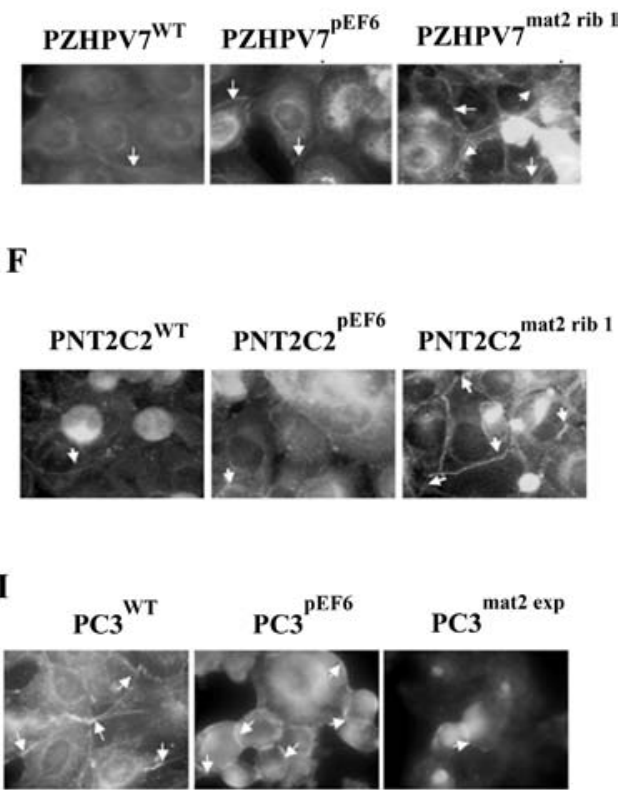

Figure 4. $\beta$-catenin expression was examined in the PZHPV7 ${ }^{\text {mat2 rib1 }}$, PNT2C2 $2^{\text {mat2 ribl }}$ and PC ${ }^{\text {mat2 exp }}$ cells. No change was observed in $\beta$-catenin mRNA expression in the PZHPV7 ${ }^{\text {mat2 rib1 }}, \mathrm{PNT}_{2} \mathrm{C}^{\text {mat2 ribl }}$ or PC $3^{\text {mat2 exp }}$ cells $(\mathrm{A}, \mathrm{D}$ and G), but an increase in $\beta$-catenin protein expression was observed, as shown by western blot analysis (B and E). The PC ${ }^{\text {mat2 exp }}$ cells, however, showed a decrease in $\beta$-catenin protein expression, as shown by western blot analysis (H). IFC revealed that the increase and decrease in $\beta$-catenin protein expression was at the cell membrane $(\mathrm{C}, \mathrm{F}$ and $\mathrm{I})$. Images shown are representative. 
established within our laboratory, as this cell line displays minimal expression levels of matriptase-2 (13). By contrast, the PZHPV7 and PNT2C2 cell lines expressed a high level of the matriptase- 2 transcript and were thus chosen as a model to target matriptase- 2 expression. Once matriptase- 2 knockdown was confirmed, these model systems were used to explore the potential correlation between matriptase- 2 and $\beta$-catenin.

Examination of the mRNA levels of $\beta$-catenin in the matriptase-2-manipulated and respective control cell lines revealed that matriptase- 2 expression status had no effect on the transcript levels of $\beta$-catenin. In light of this, the protein levels of $\beta$-catenin were then examined using western blot analysis. The western blots revealed that an overexpression of matriptase- 2 greatly decreased the protein levels of $\beta$-catenin in the PC $3^{\text {mat2 exp }}$ cell line. Conversely, in the matriptase-2 knockdown cells, PZHPV7 ${ }^{\text {mat2 rib1 }}$ and PNT2C2 $2^{\text {mat2 rib1 }}$, there was a large increase in $\beta$-catenin protein. These results suggest a potential role for matriptase- 2 in regulating $\beta$-catenin protein expression.

To further examine the protein expression of $\beta$-catenin, IFC was conducted on all cell lines. This also revealed a decrease in $\beta$-catenin expression in the PC $3^{\text {mat2 exp }}$ cells, where the lack of fluorescence was clearly visible. As with the western blot analysis, the PZHPV7 ${ }^{\text {mat2 rib1 }}$ and PNT2C $2^{\text {mat2 rib1 }}$ cells also showed an increase in $\beta$-catenin protein staining. The regulation of $\beta$-catenin protein by matriptase- 2 was apparent at the cell membrane location. As matriptase- 2 is also found at the cell membrane, it is in the ideal place to affect $\beta$-catenin. This change in $\beta$-catenin levels in the cells may account for the changes in motility and invasion observed in the cells, as $\beta$-catenin target genes are often involved in regulating such cellular processes. The exact manner in which matriptase- 2 performs this regulatory action currently remains unknown. One potential theory is that matriptase- 2 may affect extracellular signals that would have a knock-on effect on $\beta$-catenin.

Matriptase-2 plays a complex role in prostate cancer cells. This study has provided additional evidence that matriptase- 2 may have a protective function in preventing the development and progression of prostate cancer. It may utilise its proteolytic action toward the regulation of $\beta$-catenin to bring about this protective function. Further investigation is required in order to fully elucidate the correlation between matriptase- 2 and $\beta$-catenin and to identify whether this may be a key mechanism in the protective function of matriptase- 2 in prostate cancer progression.

\section{Acknowledgements}

The authors wish to thank Cancer Research Wales for supporting this study.

\section{References}

1. Lang JC and Schuller DE: Differential expression of a novel serine protease homologue in squamous cell carcinoma of the head and neck. Br J Cancer 84: 237-243, 2001.

2. Lee JW, Yong Song S, Choi JJ, et al: Increased expression of matriptase is associated with histopathologic grades of cervical neoplasia. Hum Pathol 36: 626-633, 2005.

3. Magee JA, Araki T, Patil S, et al: Expression profiling reveals hepsin overexpression in prostate cancer. Cancer Res 61: 5692-5696, 2001.
4. Netzel-Arnett S, Hooper JD, Szabo R, et al: Membrane anchored serine proteases: a rapidly expanding group of cell surface proteolytic enzymes with potential roles in cancer. Cancer Metastasis Rev 22: 237-258, 2003.

5. Wallrapp C, Hahnel S, Muller-Pillasch F, et al: A novel transmembrane serine protease (TMPRSS3) overexpressed in pancreatic cancer. Cancer Res 60: 2602-2606, 2000.

6. Velasco G, Cal S, Quesada V, Sanchez LM and Lopez-Otin C: Matriptase-2, a membrane-bound mosaic serine proteinase predominantly expressed in human liver and showing degrading activity against extracellular matrix proteins. J Biol Chem 277: 37637-37646, 2002.

7. Hooper JD, Campagnolo L, Goodarzi G, Truong TN, Stuhlmann H and Quigley JP: Mouse matriptase-2: identification, characterization and comparative mRNA expression analysis with mouse hepsin in adult and embryonic tissues. Biochem J 373: 689-702, 2003.

8. Szabo R and Bugge TH: Type II transmembrane serine proteases in development and disease. Int $\mathrm{J}$ Biochem Cell Biol 40: 1297-1316, 2008.

9. Shi YE, Torri J, Yieh L, Wellstein A, Lippman ME and Dickson RB: Identification and characterization of a novel matrix-degrading protease from hormone-dependent human breast cancer cells. Cancer Res 53: 1409-1415, 1993.

10. Tsai WC, Chu CH, Yu CP, et al: Matriptase and survivin expression associated with tumor progression and malignant potential in breast cancer of Chinese women: tissue microarray analysis of immunostaining scores with clinicopathological parameters. Dis Markers 24: 89-99, 2008

11. Uhland K: Matriptase and its putative role in cancer. Cell Mol Life Sci 63: 2968-2978, 2006.

12. Parr C, Sanders AJ, Davies G, et al: Matriptase-2 inhibits breast tumor growth and invasion and correlates with favorable prognosis for breast cancer patients. Clin Cancer Res 13: 3568-3576, 2007.

13. Sanders AJ, Parr C, Martin TA, Lane J, Mason MD and Jiang WG: Genetic upregulation of matriptase- 2 reduces the aggressiveness of prostate cancer cells in vitro and in vivo and affects FAK and paxillin localisation. J Cell Physiol 216: 780-789, 2008.

14. Hart M, Concordet JP, Lassot I, et al: The F-box protein beta-TrCP associates with phosphorylated beta-catenin and regulates its activity in the cell. Curr Biol 9: 207-210, 1999.

15. He TC, Sparks AB, Rago C, et al: Identification of c-MYC as a target of the APC pathway. Science 281: 1509-1512, 1998.

16. Brabletz T, Jung A, Dag S, Hlubek F and Kirchner T: beta-catenin regulates the expression of the matrix metalloproteinase-7 in human colorectal cancer. Am J Pathol 155: 1033-1038, 1999.

17. Crawford HC, Fingleton BM, Rudolph-Owen LA, et al: The metalloproteinase matrilysin is a target of beta-catenin transactivation in intestinal tumors. Oncogene 18: 2883-2891, 1999.

18. Zhang X, Gaspard JP and Chung DC: Regulation of vascular endothelial growth factor by the Wnt and K-ras pathways in colonic neoplasia. Cancer Res 61: 6050-6054, 2001.

19. Boon EM, van der Neut R, van de Wetering M, Clevers $H$ and Pals ST: Wnt signaling regulates expression of the receptor tyrosine kinase met in colorectal cancer. Cancer Res 62: 5126-5128, 2002.

20. Chesire DR, Ewing CM, Sauvageot J, Bova GS and Isaacs WB: Detection and analysis of beta-catenin mutations in prostate cancer. Prostate 45: 323-334, 2000.

21. Gerstein AV, Almeida TA, Zhao G, et al: APC/CTNNB1 (betacatenin) pathway alterations in human prostate cancers. Genes Chromosomes Cancer 34: 9-16, 2002.

22. Voeller HJ, Truica CI and Gelmann EP: Beta-catenin mutations in human prostate cancer. Cancer Res 58: 2520-2523, 1998.

23. Chesire DR, Ewing CM, Gage WR and Isaacs WB: In vitro evidence for complex modes of nuclear beta-catenin signaling during prostate growth and tumorigenesis. Oncogene 21: 2679-2694, 2002.

24. de la Taille A, Rubin MA, Chen MW, et al: Beta-catenin-related anomalies in apoptosis-resistant and hormone-refractory prostate cancer cells. Clin Cancer Res 9: 1801-1807, 2003.

25. Gounari F, Signoretti S, Bronson R, et al: Stabilization of betacatenin induces lesions reminiscent of prostatic intraepithelial neoplasia, but terminal squamous transdifferentiation of other secretory epithelia. Oncogene 21: 4099-4107, 2002.

26. Bierie B, Nozawa M, Renou JP, et al: Activation of beta-catenin in prostate epithelium induces hyperplasias and squamous transdifferentiation. Oncogene 22: 3875-3887, 2003. 